\begin{tabular}{|l|l|l}
\hline Received : December 2017 & Accepted: December 2017 & Published : January 2018 \\
\hline
\end{tabular}

\title{
Bidai dan Takin dalam Perspektif Sosio-Ekonomi Masyarakat Perbatasan Indonesia-Malaysia
}

\author{
Jumardi Budiman \\ Sekolah Tinggi Ilmu Ekonomi Indonesia Pontianak
}

jumardib@gmail.com

\begin{abstract}
The context of this research was on the phenomenon of economy and socio culture mobilities on Dayaknese society in Seluas and Jagoi Babang district which are Indonesia - Malaysia borderland. The economy and social mobilities occured on the trade of plaited handicraft Bidai and Takin which are the culture heritage of Dayaknese society in Indonesia-Malaysia borderland. The approach used in this research was qualitative approach by data validity test such as credibility, dependability, and confirmability tests. Source of data and the informen as well in this research were the craftsmen and distributors of Bidai and Takin. The resesarch finding showed there was the economy mobilities such as the plaited handicraft products trading and the social mobilities such as the claim of the culture heritage rights by the distributor from Malaysia.
\end{abstract}

Keywords: bidai and takin, socio-economy, borderland people

\begin{abstract}
Abstrak
Konteks penelitian ini adalah pada fenomen mobilitas ekonomi dan sosial budaya masyarakat Dayak di Kecamatan Seluas dan Jagoi Babang yang merupakan kawasan perbatasan Indonesia Malaysia. Mobilitas ekonomi dan sosial terjadi pada perdagangan kerajinan anyaman Bidai dan Takin yang merupakan warisan budaya masyarakat Dayak perbatasan Indonesia-Malaysia. Pendekatan yang digunakan dalam penelitian ini adalah pendekatan kualitatif dengan pengecekan keabsahan data meliputi uji kredibilitas, uji dependability dan uji confirmability. Sumber data sekaligus informan dalam penelitian ini adalah pengerajin dan pengepul kerajinan anyaman Bidai dan Takin. Hasil penelitian menunjukkan bahwa terjadi mobilitas ekonomi berupa perdagangan produk kerajinan dan mobilitas sosial berupa pengakuan hak cipta warisan budaya oeh pengepul dari Malaysia.
\end{abstract}

Kata kunci: bidai dan takin, sosio-ekonomi, masyarakat perbatasan

\section{Pendahuluan}

\subsection{Konteks Penelitian}

Kecamatan Jagoi Babang, Kabupaten Bengkayang merupakan satu di antara kabupaten di Provinsi Kalimantan Barat yang berbatasan langsung dengan negara Malaysia. Kondisi geografis ini menjadikan kecamatan Jagoi Babang masuk dalam Kawasan Pengembangan Ekonomi (KPE) perbatasan Indonesia-Malaysia. Penetapan Jagoi Babang sebagai KPE memberikan konsekuensi bagi pemerintah pusat maupun pemerintah daerah untuk lebih serius mengelola kawasan ini karena menjadi gerbang utama lalu lintas perdagangan antar negara yang diharapkan mampu memberikan kontribusi bagi peningkatan kesejahteraan masyarakat yang hidup di kawasan perbatasan.

Peningkatan kesejahteraan masyarakat perbatasan, tidak hanya berimplikasi terhadap kondisi ekonomi, namun juga membawa dampak sosial sebagai warga negara. Implikasi sosial dan ekonomi sebagai 
akibat pengelolaan masyarakat kawasan perbatasan tidak dapat dipisahkan karena memiliki keterkaitan yang sangat erat. Masyarakat Indonesia kawasan perbatasan yang hidup di bawah garis kemiskinan, cenderung mudah terintimidasi dalam interaksi sosial dengan masyarakat Malaysia yang memiliki stratifikasi ekonomi yang lebih tinggi. Akibatnya, beberapa komunitas masyarakat perbatasan memilih untuk pindah dan menetap di Malaysia karena dianggap lebih mampu menjamin kehidupan yang lebih layak. Tidak mengherankan jika banyak warga Indonesia di perbatasan memiliki kartu identitas kewarganegaraan Malaysia, bersekolah dan menerima pelayanan kesehatan dari Malaysia hingga menggunakan mata uang ringgit dalam aktivitas perekonomian yang sebagian besar juga dilakukan di wilayah Malaysia. Berbagai aktivitas ini tentu saja memiliki dampak pada nasionalisme dan memiliki potensi ancaman terhadap kedaulatan bangsa (Yovinus, 2017: 90-91).

Dampak paling buruk dari mobilisasi masyarakat perbatasan yang pindah kewarganegaaran ialah ikut berpindahnya unsur-unsur budaya yang menjadi fondasi utama pola kehidupan masyarakat. Tidak mengherankan jika kemudian ditemukan banyak kesamaan dalam kebudayaan antara Indonesia dengan Malaysia yang terkadang menimbulkan konflik sosial antara pemerintah kedua negara akibat saling mengklaim pemilik budaya yang sama.

Masalah sosio-ekonomi masyarakat perbatasan Indonesia-Malaysia seperti yang dikemukakan di atas, telah terjadi selama puluhan tahun akibat pengelolaan sistem politik tersentralisasi sehingga membuat kawasan perbatasan menjadi terbelakang dari segi ekonomi, terbaikan dari segi kebijakan dan terpencil dari segi sarana penghubung (Tangkilisan, 2013: 89). Padahal, daerah perbatasan yang termasuk dalam KPE memiliki kriteria sebagai daerah pengembangan kawasan industri berskala besar serta merupakan tempat pelestarian adat-istiadat dan budaya nasional (Edyanto, 2007:120), sehingga mampu menjadi basis utama pertahanan keamanan dan kedaulatan negara.

Penanggulangan masalah sosioekonomi masyarakat perbatasan, memang telah dilakukan pemerintah dalam beberapa tahun terakhir, namun upaya tersebut masih berorientasi pada dampak (misal perdagangan ilegal) dan bukan pada sumber (misal peningkatan kualitas SDM). Pengupayaan pengentasan masalah perbatasan Indonesia-Malaysia masih berorientasi pada aspek fisik (sarana/ fasilitas penunjang), namun belum menyentuh ranah psikologis warga perbatasan. Kondisi ini diperparah dengan kualitas lembaga pendidikan daerah perbatasan yang dikelola secara tidak efektif dan efisien. Belum 
seriusnya upaya perbaikan kualitas SDM berdampak melahirkan gejala masyarakat perbatasan berorientasi pada keuntungan finansial sehingga mengabaikan aspek pelestarian budaya dan kearifan lokal.

Fenomena pengabaian aspek pelestarian budaya dan kearifan lokal ini tampak pada proses perdagangan kerajinan Bidai dan Takin. Bidai adalah kerajinan rotan yang berbentuk persegi dan atau persegi panjang yang biasa digunakan masyarakat sebagai tikar. Adapun Takin ialah anyaman dari kulit rotan berbentuk silinder yang digunakan masyarakat untuk menyimpang benih saat menanam padi. Kerajinan khas masyarakat Dayak Kabupaten Bengkayang ini sebenarnya menjadi produk andalan daerah, namun karena alasan ekonomi, masyarakat lebih memilih menjual produk tersebut kepada pengepul di Malaysia daripada menjual di dalam negeri. Harga jual kerajinan Bidai dan Takin di Malaysia memang jauh lebih mahal jika dibandingkan dengan Indonesia. Selain itu, permintaan pasar di Malaysia lebih tinggi daripada pasar domestik.

Sekilas, perdaganan kerajinan antar negara ini tampak seperti perdagangan biasa, namun ternyata kegiatan ekonomi ini membawa dampak sosial yang sebenarnya sudah disadari oleh para pengrajin. Bidai dan Takin yang sudah dibeli pengepul di Malaysia kemudian dikemas dengan menarik, diberi label "buatan Malaysia" dan dijual kembali ke pasar eropa dengan harga yang jauh lebih tinggi. Bahkan berdasarkan informasi yang diperoleh, kerajinan yang sudah dikemas ulang tersebut juga dijual di pasar seni kepulauan Bali yang menyasar pada wisatawan asing.

Berlandaskan pada fenomena ini, peneliti mencoba mengkaji kegiatan kerajinan Bidai dan Takin berdasarkan perspektif sosio-ekonomi masyarakat daerah perbatasan. Perspektif sosio-ekonomi dipilih karena keyakinan bahwa segala masalah ekonomi dapat dipecahkan dengan optimal jika dikombinasikan dengan ilmu sosial yang lain (Damsar, 2012:3). Segala tindakan ekonomi yang dilakukan masyarakat tidak terlepas dari proses interaksi sosial, stratifikasi sosial dan norma sosial yang ada.

\subsection{Fokus Penelitian}

Fokus penelitian ini pada kegiatan perdagangan kerajinan Bidai dan Takin yang ditinjau dari perspektif sosio-ekonomi masyarakat kawasan perbatasan IndonesiaMalaysia.

\section{Metode Penelitian}

\subsection{Pendekatan Penelitian}

Pendekatan yang digunakan dalam penelitian ini adalah penelitian kualitatif karena peneliti ingin mengungkapkan secara komprehensif tentang aspek sosial yang menjadi penyebab perdagangan kerajinan. Pendekatan kualitatif dipilih karena alasan berikut: (1) realitas yang ada pada dasarnya bersifat ganda, terkonstruksi dan holistik; (2) 
antara orang yang mengetahui dan diketahui bersifat interaktif dan tidak dapat dipisahkan; (3) hanya waktu dan konteks yang memungkinkan berkaitan dengan hipotesis kerja; (4) semua entitas yang ada dalam kondisi yang saling simultan sehingga tidak mungkin membedakan sebab-akibat; penelitian pada dasarnya bebas dari nilai (Lincoln dan Guba dalam Sugiono, 2005:5455). Orientasi teoritis yang digunakan dalam penelitian ini adalah fenomenologis karena penelitian didasarkan pada suatu fenomena yang dirasakan yakni perdagangan kerajninan antara negara memberikan dampak sosial yakni mobilitas produk budaya dan kearifan lokal masyarakat perbatasan.

Pendekatan kualitatif dalam penelitian ini bersifat alamiah, deskriptif dan induktif. Alamiah karena semua proses yang terjadi tidak didasarkan atas perlakuan peneliti. Bersifat deskriptif karena dalam penelitian ini laporan penelitian diuraikan dalam bentuk penjabaran yang didukung oleh kata-kata (hasil wawancara) guna memudahkan pengungkapan hasil penelitian. Bersifat induktif karena peneliti tidak bermaksud menguji teori yang telah ada, namun lebih membuat abstraksi terhadap fakta-fakta yang terkumpul.

\subsection{Peran Peneliti}

Peran peneliti dalam penelitian ini adalah sebagai pengumpul data yang bertindak sebagai pengamat penuh. Artinya, peneliti tidak berpartisipasi dalam gejala yang atau tindakan sosial yang terjadi. Peneliti hanya mengumpulkan data yang diperlukan bagi penelitian. Selama proses penelitian, status peneliti diketahui oleh informan atau sumber data.

\subsection{Lokasi dan Subjek Penelitian}

Lokasi penelitian ini adalah di Kecamatan Seluas dan Kecamatan Jagoi Babang Kabupaten Bengkayang Provinsi Kalimantan Barat. Subjek penelitian sekaligus umber data yang dijadikan subjek penelitian sekaligus informan dalam penelitian ini adalah pengrajin sekaligus pedagang Bidai dan Takin yang berjumlah enam orang serta perwakilan Dinas Koperasi dan UMKM sebanyak satu orang.

\subsection{Teknik Pengumpulan Data}

Pengumpulan data pada penelitian kualitatif dilakukan pada kondisi yang alamiah sehingga memerlukan teknik pengumpulan data yang tepat. Teknik pengumpulan data pada penelitian kualitatif lebih banyak pada observasi berperan serta, wawancara mendalam dan dokumentasi.

\subsection{Teknik Pengolahan Data}

Aktivitas dalam analisis data yaitu data reduction, data display dan conclusion drawing/verivication. Pengecekan kebasahan data temuan penelitian dimaksudkan agar data yang diperoleh valid dan dapat dipertanggungjawabkan. Teknik pengecekan keabsahan data penelitian ini meliputi uji 
kredibilitas, uji dependability dan uji confirmability.

\section{Hasil Penelitian}

\subsection{Potensi dan Peluang Bidai}

Masyarakat adat Dayak di Kabupaten Bengkayang telah lama menekumi seni kerajinan sebagai bagian dari pola kehidupan sosial masyarakat. Pada awalnya teknik dan produk kerajinan ini hanya digunakan untuk keperluan pribadi atau keluarga. Seiring berjalannya waktu, banyak pihak dari luar Kabupaten Bengkayang yang tertarik memiliki produk kerajinan yang dihasilkan, sehingga menjadi suatu peluang usaha bagi beberapa masyarakat di Bengkayang. Produk kerajinan khas Kabupaten Bengkayang yang paling diminati adalah Bidai. Bidai merupakan produk kerajinan berbentuk tikar yang paling khas dari Kabupaten Bengkayang karena tidak ditemukan di daerah lain. Sentra produksi Bidai di Kabupaen Bengkang terdapat di dua kecamatan yakni di Kecamatan Seluas dan Kecamatan Jagoi babang.

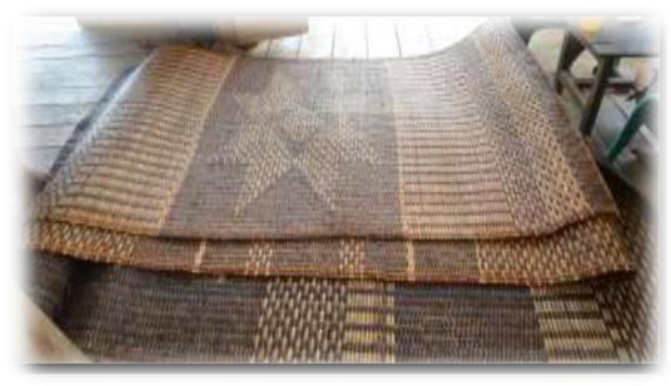

Gambar 1. Produk Bidai
Pada awalnya, motif pada kerajinan Bidai memiliki pola tertentu yang memiliki makna tersendiri. Namun kini, motif pada Bidai dibuat hanya berdasarkan keinginan pengrajin atau sesuai pesanan konsumen. Mulai dari motif simetris, garis-garis, motif insang, motif segitiga sampai pada motif huruf yang dapat dibaca. Bahan baku bidai adalah rotan dan kulit kayu ( dalam bahasa daerah masyarakat disebut kapua’ ). Rotan yang digunakan adalah jenis rotan putih dan rotan saga karena memiliki nilai estetika dan kelenturan yang pas untuk anyaman Bidai. Adapun kulit kayu ( kapua' ) digunakan sebagai tali pengikat dan alas (dasar) anyaman Bidai. Anyaman Bidai yang memiliki potensi dan nilai jual tinggi, masih terkendala pada aspek pengadaan bahan baku berupa rotan dan kulit kayu yang semakin sulit diperoleh dari hutan lokal sehingga harus didatangkan dari provinsi lain. Ketersediaan rotan yang semakin minim di Kabupaten Bengkayang disebabkan belum ada upaya membudidayakan rotan dan masih mengandalkan rotan liar yang ada di hutan. Saat ini bahan baku rotan didatangkan dari Kalimantan Tengah yang memiliki rotan dalam jumlah banyak. Kondisi ini patut dikhawatirkan oleh para pengrajin dan pengepul karena distribusi rotan dari pemasok yang kadang tidak terlalu lancar dan harga rotan yang semakin mahal.

Proses produksi bidai masih dikerjakan secara manual menggunakan bahan-bahan 
alami. Misalnya proses mewarnai pada bidai, masih menggunakan air rebusan daun pohon rambutan yang dimasak selama satu hari. Setelah direbus, rotan yang diwarnai kemudian direndam di lumpur selama 1-2 hari agar warna hitam meresap hingga ke serat rotan. Proses pengolahan kulit kayu juga menggunakan alat manual dan pengerjaannya mengandalkan tenaga untuk memukul kulit kayu tersebut hingga lentur dan berbentuk seperti kain kasar. Penganyaman bidai dikerjakan secara manual, tanpa bantuan mesin atau teknologi membuat kegiatan produksi satu buah bidai memerlukan waktu yang lama. Selain itu, faktor motivasi dan ketersediaan waktu penganyam juga menentukan waktu pembuatan bidai.

Anyaman bidai sudah teruji memiliki ketahanan dari segi kualitas sehinga awet digunakan untuk keperluan sehari-hari. Bahkan, semakin sering digunakan, tikar bidai semakin lentur, licin dan dingin sehingga nyaman digunakan. Anyaman bidai pada awalnya berfungsi sebagai tikar bagi keluarga suku Dayak kawasan perbatasan. Seiring perkembangan zaman, kerajinan bidai saat ini lebih dihargai sebagai produk seni. Kegunaannyapun semakin beragam; tikar (sebagai alas lantai), hiasan dinding, alas sajadah, hingga sebagai bahan pembuatan tas jinjing bagi wanita. Berdasarkan keyakinan masyarakat perbatasan, anyaman bidai berbahan dasar rotan dan memiliki permukaan yang bergelombang, dipercaya dapat melancarkan peredaran darah sehingga sangat baik untuk kesehatan. Hal ini yang membuat sebagian masyarakat menggunakan bidai sebagai alas untuk tidur.

Peminat anyaman bidai tak hanya dari sekitar Kabupaten Bengkayang dan pasar domestik Kalimantan Barat, namun juga dari Malaysia. Bahkan berdasarkan informasi yang diperoleh peneliti, jumlah pesanan anyaman Bidai dari Malaysia justru lebih banyak dan bersifat berkelanjutan. Setiap minggu, pengepul bidai membawa beberapa hasil kerajinan ke Pasar Serikin yang merupakan pasar bebas daerah perbatasan Indonesia - Malaysia. Anyaman bidai dijual dengan standar mata uang ringgit yang jika dikonversikan dalam bentuk rupiah, harga sebuah anyaman bidai sebesar Rp. 500.00 s/d Rp. 1000.000, tergantung dari ukuran, motif dan permintaan pasar. Bidai yang memiliki ukuran dan motif sama bisa dijual dengan harga berbeda jika kondisi pasar menunjukkan trend positif misalnya menjelang hari raya keagamaan. Namun bila pasar lesu, harga jual bidai dapat lebih murah. Tidak ada standar khusus tentang harga jual bidai, semuanya tergantung dari proses tawar menawar antara pengepul dengan konsumen atau antar sesama pengepul bidai. Harga ini dinilai cukup mahal untuk lingkup masyarakat di Kabupaten Bengkayang sehingga produk ini 
lebih laku jika dijual di pasar perbatasan dengan Malaysia.

\subsection{Potensi dan Peluang Takin}

Takin merupakan kerajinan anyaman dari rotan yang berbentuk silinder (tabung). Pada awalnya, takin berukuran besar yang digunakan para petani untuk membawa berbagai barang, bekal atau hasil panen dari ladang. Kemudian Takin dibuat dalam ukuran yang lebih kecil untuk digunakan sebagai tas selempang dengan menggunakan tali kapua'.

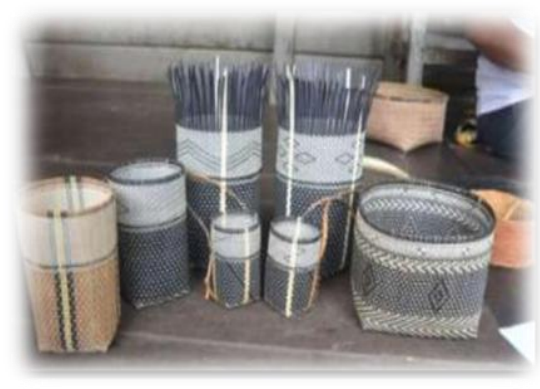

Gambar 2. Produk Takin

Saat ini pembuatan takin yang berukuran kecil lebih ditujukan sebagai souvenir karena memiliki nilai seni yang tinggi. Sentra pembuatan Takin terletak di Dusun Jagoi Kindau Desa Sekidau Kecamatan Jagoi Babang. Dusun Jagoi Kindau merupakan daerah perbukitan dengan akses jalan yang sempit. Oleh karena itu, keberadaan dusun ini sebagai sentra kerajinan takin hanya diketahui oleh penduduk sekitar dan pengepul yang menjadi pembeli tetap produk ini. Hal ini diperparah dengan minimnya promosi baik dari pengrajin maupaun dari dinas terkait sehingga produk ini lebih dikenal masyarakat Malaysia.
Takin (beberapa masyarakat menyebutnya Juah) pada umumnya berbentuk tabung dengan diameter dan tinggi yang berbeda sesuai keperluan dan pesanan konsumen. Walau bentuknya sederhana, namun motif dan nilai seni yang tinggi membuat kerajinan ini memiliki daya tarik tersendiri dibandingkan kerajinan anyaman rotan yang lain. Kelebihan produk takin yakni memiliki nilai praktis yang dapat digunakan untuk keperluan sehari-hari seperti tas selempang untuk menyimpan benih padi, sebagai vas bunga, sebagai tempat pensil, tempat menyimpan uang receh dan sebagai wadah menyimpang barangbarang keperluan sehari-hari. Kelebihan lain yakni motif pada badan takin yang semakin beragam, bahkan beberapa pengrajin dapat membuat motif huruf balok seperti huruf "K", "M", "N", dan beberapa huruf berbentuk dasar garis tanpa lengkung. Anyaman takin bersifat lentur sehingga memungkinkan untuk divariasikan menjadi berbagai bentuk kerajinan seperti bentuk vas bunga, bentuk persegi dan persegi panjang. Motif pada badan takin juga dapat dikreasikan dengan motif-motif lain sesuai daya kreativitas pengrajin.

Kerajinan takin dibuat dengan menggunakan rotan putih masih terdapat di hutan Kabupaten Bengkayang. Pengadaan bahan baku tergantuk pada petani yang mencari rotan di Ladang. Jika petani tidak mencari rotan, maka bahan baku tidak 
tersedia. Selain itu, jenis rotan yang digunakan harus jenis tertentu seperti rotan putih yang jumlahnya semakin sedikit sehingga semakin sulit diperoleh.

Kerajinan ini dibuat dalam berbagai bentuk sehingga memiliki harga jual yang berbeda mulai dari Rp. 30.000 untuk ukuran paling kecil s/d Rp. 100.000 untuk ukuran paling besar. Harga jual yang cukup murah ini membuat takin lebih mudah dijual karena masih terjangkau oleh masyarakat.

Berdasarkan hasil wawancara dengan pengrajin takin, proses penjualan kerajinan takin dilakukan melalui perantara pengepul kerajinan yang langsung datang ke Dusun Jagoi Kindau untuk membeli takin dalam jumlah banyak. Oleh karena itu, harga jual produk ditentukan oleh pengepul dengan proses tawar-menawar dengan pengrajin. Sebagai sebuah kerajinan dengan nilai seni tinggi, produk takin sangat diminati masyarakat Malaysia sebagai hiasan rumah atau digunakan untuk keperluan sehari-hari. Hal ini terbukti masih tingginya permintaan pengepul untuk produk kerajinan takin. Setidaknya 1 sampai 2 kali pengepul datang ke Dusun Jagoi Kindau untuk membeli takin dari pengrajin.

Pengrajin takin di dusun Jagoi Kindau selama ini hanya berperan dalam proses produksi dan langsung menjual kepada pengepul tanpa melalui proses pengemasan dan pemberian merk. Hal ini beresiko menimbulkan kerentanan untuk diakui hak ciptanya oleh negara lain.

\subsection{Bidai dan Takin dalam Perspektif Sosio-Ekonomi Masyarakat Perbatasan}

Jumlah pengrajin dan pengepul bidai dari lokal semakin berkurang karena beberapa pengrajin beralih pekerjaan menjadi petani sawit. Ekspansi perkebunan sawit yang tidak dibendung membawa dampak negatif pada kerajinan anyaman Bidai. Banyak pengrajin yang beralih pekerjaan menjadi buruh perkebunan sawit sebagai pekerjaan utama dan menganyam bidai sebagai pekerjaan sampingan dengan asumsi bahwa buruh perkebunan sawit adalah pekerjaan yang mudah dilakukan dan buruh akan mendapat gaji tetap. Masyarakat juga beranggapan bahwa menjadi buruh/ karyawan di perkebunan sawit memiliki kelas sosial yang lebih tinggi daripada menjadi pengrajin. Anggapan ini pula yang menyebabkan keterampilan mengayam bidai kurang diminati di kalangan generasi muda karena dianggap ketinggalan zaman.

Dampak lain yang ditimbulkan ialah hilangnya hak-hak masyarakat untuk mengoptimalkan fungsi hutan sebagai penyedia bahan baku anyaman Bidai (rotan dan kapua') karena luas hutan semakin berkurang. Pada aspek Hak Kekayaan Intelektual, anyaman bidai yang merupakan anyaman khas dan asli dari Kabupaten Bengkayang Kalimantan Barat tidak memiliki hak cipta yang melekat pada kerajinan tersebut sehingga Bidai hasil 
kerajinan Bengkayang sering diakui sebagai produk malaysia. Modus "pencurian hak cipta" yang dilakukan para pengepul dari Malaysia yakni dengan membeli bidai dari pengrajin atau pengepul di Kecamatan Seluas dan Jagoi Babang, kemudian bidai tersebut dikemas dengan lebih menarik dan diberi label "made in Malaysia". Bidai yang sudah dikemas kemudian dikirim ke pasar Eropa, Amerika dan bahkan dijual kepada wisatawan di Bali. Kondisi ini sangat disayangkan karena bidai merupakan warisan budaya asli Indonesia berbentuk kebendaan yang semestinya memiliki hak cipta.

Persoalan pengakuan hak cipta ini sebenarnya sudah disadari baik oleh pengrajin, pengepul lokal bahkan pemerintah daerah. Pengrajin dan pengepul lokal sendiri tidak memiliki kapabilitas dalam mengatasi persoalan ini meskipun mereka adalah produsen dari produk yang dihasilkan. Permintaan dan harga jual yang tinggi dari pengepul dari Malaysia membuat pengrajin harus mengikuti permintaan pasar yakni dengan tidak memberi label apapun terhadap hasil kerajinan mereka. Jika permintaan pasar ini tidak diindahkan, maka produk mereka tidak akan laku di pasaran. Penyebab lain yang menghambat klaim atas produk bidai yang dihasilkan masyarakat adalah faktor sejarah dan rumpun suku masyarakat. Sejak beberapa periode, masyarakat Dayak juga telah mendiami dan menjadi warga negara Malaysia sehingga praktis mereka juga memiliki hak atas warisan budaya suku Dayak. Jika masyarakat Dayak yang mendiami kawan perbatasan Indonesia mengklaim bahwa Bidai merupakan warisan budaya mereka, maka masyarakat Dayak warga negara Malaysia juga bisa melakukan hal serupa karena ternyata kerajinan Bidai juga diproduksi di Malaysia, meskipun kualitasnya masih di bawah Bidai buatan Indonesia.

Femonema serupa juga terjadi di Dusun Jagoi Kindau yang merupakan sentra pembuatan kerajinan Takin. Langkanya bahan baku berupa rotan dan tidak tertariknya generasi muda untuk belajar menganyam Takin membuat keberlanjutan produk kerajinan ini menghadapi masalah serius. Tidak berdayanya pengrajin Takin terhadap permintaan pengepul dari Malaysia yang merupakan pelanggan tetap produk ini, berakibat pada hilangnya hak cipta yang melekat pada produk tersebut. Terlebih, dusun ini terletak di area perbukitan sehingga jarang dikunjungi oleh wisatawan lokal sehingga pengrajin tidak memiliki alternatif pembeli lain.

Ditinjau dari aspek tindakan sosial (yang tidak terlepas dari motif ekonomi), keputusan para pengrajin Bidai dan Takin dapat diterima secara logika. Sebagai produsen, tujuan utama mereka adalah agar produk yang dihasilkan memiliki nilai jual yang optimal di pasar. Guna mencapai tujuan 
tersebut, maka berlaku hukum permintaan dan penawaran yakni permintaan dan harga penawaran yang tinggi dari pasar Malaysia menjadi orientasi utama dari pengrajin. Orientasi pada nilai jual produk inilah yang kemudian menjadi celah bagi pengepul Malaysia untuk bisa mendapatkan laba yang lebih tinggi yakni dengan menjual kembali produk bernilai seni tinggi itu ke pasar Eropa dengan terlebih dahulu mengklaim bahwa produk kerajinan tersebut merupakan hasil produksi dalam negeri Malaysia.

\section{Kesimpulan}

Simpulan dari penelitian ini adalah bahwa kerajinan Bidai dan Takin tidak sekedar menjadi produk seni yang memiliki nilai jual dari aspek ekonomi. Lebih dari itu, Bidai dan Takin merupakan warisan budaya yang tidak terpisahkan dari kehidupan sosial masyarakat Dayak kawasan perbatasan Indonesia-Malaysia. Kendala utama yang dihadapi pengrajin Bidai dan Takin yakni ketersediaan bahan baku, pencurian hak cipta dan semakin rendahnya minat generasi muda dalam mempelajari dan melestarikan warisan budaya ini.

\section{Saran}

Saran yang dapat penulis sampaikan, hendaknya pemerintah daerah dan pemerintah pusat lebih serius dalam melestarikan kerajinan Bidai dan Takin, tidak sekedar menjadikan produk tersebut sebagai "pajangan" saat kegiatan pameran produk lokal. Kebijakan nyata dalam memberdayakan para pengrajin serta melindungi hak cipta atas produk ini sangat diperlukan.

\section{Daftar Pustaka}

Damsar. (2012). Sosiologi Ekonomi. Jakarta: PT Raja Grafindo Persada

Edyanto, Herman, CB. Jurnal Sains dan Teknologi Indonesia, Vol. 9 No. 3 Desember 2007 Hlm. 120-129

Sugiono. (2005). Memahami Penelitian Kualitatif. Bandung: Alfabeta

Tangkilisan, Yuda. B. SUSURGALUR: Jurnal Kajian Sejarah \& Pendidikan Sejarah, No.1, Vol.1, Maret 2013

Yovinus, Jurnal Caraka Prabu, Vol. 1 N0. 01 Juni 2017 Hlm 90-91. 